\title{
THE ROLE OF LODZ FESTIVALS IN PROMOTING ADVENTURE TOURISM

\author{
Lodz festivals in promotion of tourism
}

WALDEMAR CUDNY, RAFAŁ ROUBA

\author{
University of Lodz, Branch of the University of Lodz in Tomaszów Mazowiecki, Institute of Tourism
Mailing address: Waldemar Cudny, Branch of the University of Lodz, 65/67 Konstytucji 3 Maja Street, 97-200 Tomaszów Mazowiecki, tel./fax: +48 44 7249720, email: algernon1@neostrada.pl

\begin{abstract}
This article discusses the role of two Lodz festivals (the Explorers Festival and the Wreck Diving Festival) in promoting adventure tourism and developing tourism in a postindustrial city such as Lodz.
\end{abstract}

Key words: adventure tourism, Lodz, festivals

\section{Introduction}

This article deals with two festivals organized in Lodz that are connected with adventure tourism. The authors have subjected two Lodz festivals to analysis: the Explorers Festival and the Wreck Diving Festival. The goal of the paper was to characterize these events and the role they play in promoting adventure tourism and in developing tourism product of postindustrial city such as Lodz.

Lodz, as an industrial city, was founded in the 19th century within the borders of the Polish Kingdom. Its development was based on textiles; thanks to this industrial specialization the city experienced rapid demographic and geographic expansion. After Poland became independent in 1918, Lodz continued to fulfill the function of the headquarters of the Polish textile industry. The traditional economic structure was maintained after 1945, when factories with $19^{\text {th }}$ century roots were nationalized and converted into large state concerns. These concerns produced fibers, textiles and clothing primarily for the USSR market. In 1989, Poland entered a new phase of so-called system transformation. Democratic governments were introduced into the country, and in the place of a centrally planned economy arose a free market. Unfortunately, most of the textile factories in Lodz failed to survive the beginning of the economic transformation. Due to excessively high production costs, outdated technology and management errors, and as a result of the loss of the USSR consumer market, these factories went bankrupt. After 1989 city authorities began searching for new roads for socioeconomic development. One of the priority directions chosen was the development of services, including tourism services (Fig. 1). Particular emphasis is currently placed in Lodz on the development of festivals, of which the city currently (2010) organizes 60 annually [1].

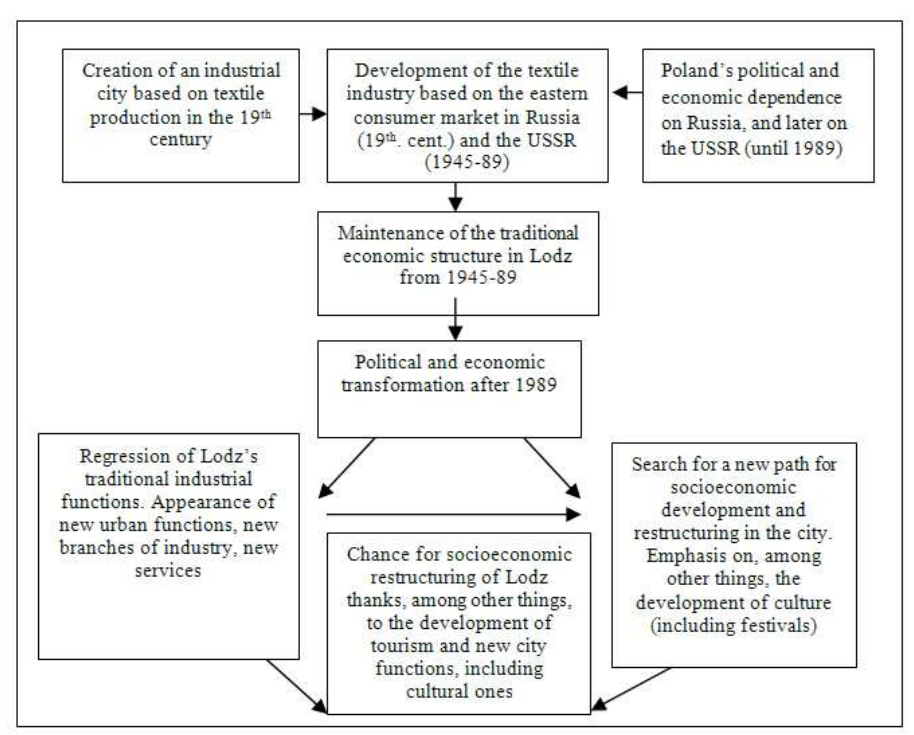

Figure 1. Diagram of socioeconomic changes in Lodz caused by the transformation [2]

\section{The concept of adventure tourism}

The festivals described in this article constitute an element of the phenomenon broadly defined as tourism. This is because they are connected with travel, discoveries and expeditions of a geographical and tourism-based nature. Their classification as a tourist product is also due to the fact that they constitute an offer for invited guests, who often travel from all over Poland and abroad to attend the festival.

Tourism-based values consist of the totality of the elements of the natural environment and non-natural elements that are of interest to tourists and that determine the attractiveness of a given location, city or area for tourists. These values may be grouped as natural or anthropogenic (cultural) [3]. The festivals 
described in this article belong to the latter group. These events also constitute a certain (market) offer for tourists, and hence are a tourism product of the city of Lodz. Among the many types of tourism products, a prominent role is played by tourism event products. These are characterized by a high degree of thematic and organizational cohesiveness, as well as by their being located in a specific place and time. Typical features of such a product also include exceptionalness, and their occasional and cyclical nature. This group of products includes various shows, presentations, exhibitions and festivals [4]. Some authors, within the framework of tourism, even distinguish a separate category termed event tourism. The goal of this kind of tourism is to take part in events that have the character of surveys, competitions and festivals, i.e. in the events themselves [5]. The festivals described in this article relate to problems connected with travel, extreme sport activities, geographic and tourist expeditions. Due to the nature of the activities, invited guests and the audiences observing them are connected with specific types of tourism. These include: qualified tourism, sport tourism and adventure tourism.

Tourism is an extremely complicated phenomenon. For this reason as well there exist numerous criteria for its division into groups. The phenomenon of tourism may be grouped based on the number of participants, their age, the season, the goal of the expeditions, etc. Based on the objectives of the expedition, one can distinguish the so-called categories of tourism. One of these is qualified tourism, which may be defined as the highest form of specialized tourism. Engaging in this form of tourism requires special psychophysical preparation, resilience in the face of hardship, an ability to function in a natural environment and in tourism features. In certain cases, engaging in such tourism requires skills certified by appropriate organizations for the use of tourism equipment, e.g. bicycle, sailboat, skis, diving equipment, etc. The objective of qualified tourism activity is relaxation, recreation, improvement of health and physical fitness, as well as comprehensive familiarization with a given country [6]. The five most important features of qualified tourism are [7]:

1. Qualified tourism is the highest form of specialization in the selected tourism discipline. One of the goals of engaging in it is to perfect ones skills and to achieve the highest level of specialization in a given discipline.

2. A qualified tourist improves his or her psychophysical fitness by engaging in this type of tourism.

3. Qualified tourism is connected with the need to possess skills in the use of specialized sporting and tourism equipment.

4. A qualified tourist should possess comprehensive knowledge about the environment and an ability to increase that knowledge. He or she should promote knowledge of a given country.

5. Qualified tourism may include competitive elements.

In English-language literature, the term sport tourism also appears. This term has certain connections with qualified and adventure tourism. In highly developed countries, this kind of tourism accounts at present for around 1 to $2 \%$ of the Gross National Product (GNP), while the entire tourism sector generates around 4 to $6 \%$ of the GNP. The sport tourism service sector is increasing in these countries at a rate of $10 \%$ annually. Sport and tourism were treated for many years as separate elements. However, in recent years this approach has changed, because a close connection was noted between tourism and sport. In the first place, sporting events have tourism value in that they attract spectators - tourists - from all over the world. A perfect example in this case is the Olympic Games or the World Cup in Football. These events call for the creation of a series of infrastructure elements that can later be used by tourists and others, e.g. sport and recreation facilities, stadiums, hotels, roads, etc. Thanks to national sporting events, countries, cities and regions promote their tourism offers and maintain a positive image. On the other hand, tourism often generates new sporting disciplines which, as time passes, occasionally ascend to the ranks of Olympic sporting events, e.g. snowboarding. Furthermore, various sporting disciplines are included in qualified and adventure tourism. These are, e.g.: running, swimming, skiing, diving, etc. [8].

Two types of sport tourism are distinguished in tourism literature:

1. Tourism connected with professionals participating in sporting events.

2. Tourism based on observation of these events as a spectator.

In this group, tourism value for sport tourism may be enjoyed by sporting events and objects connected with sports competitions or activities (stadiums, golf courses, sports and recreation facilities, but also museums connected with sports), as well as areas in which sports can be played (not always in an organized, competitive form, so-called non-competitive activities), as e.g. mountains, rivers, ice floes, etc [8].

On the other hand, adventure tourism, in its broader sense, is closely connected with qualified tourism, and is even occasionally treated as a part thereof [9]. Qualified and adventure tourism possess a series of common features (Fig. 2). Adventure tourism requires abilities and physical training proper to sports competitors. However, due to its unique character, it is specified as a separate type of tourism. This is connected with the concept of adventure, which is an event that meets the following necessary conditions:

- $\quad$ an uncertain result connected with the fact that we do not know whether we will attain the intended goal,

- $\quad$ danger and risk based on the unknown dangers and challenges we face during an expedition,

- challenge - based on facing new, unknown problems and situations,

- $\quad$ anticipation of awards connected with our achievements,

- the taste of novelty arising from participation in unusual events,

- $\quad$ stimulation, emotional and otherwise, connected with the overcoming of difficulties,

- $\quad$ isolation, solitude during an expedition, departure from the everyday,

- $\quad$ exploration and discovery of new territories, events, development of abilities, knowledge and self-confidence,

- concentration required for the realization of our intentions,

- $\quad$ contradictory emotions [10].

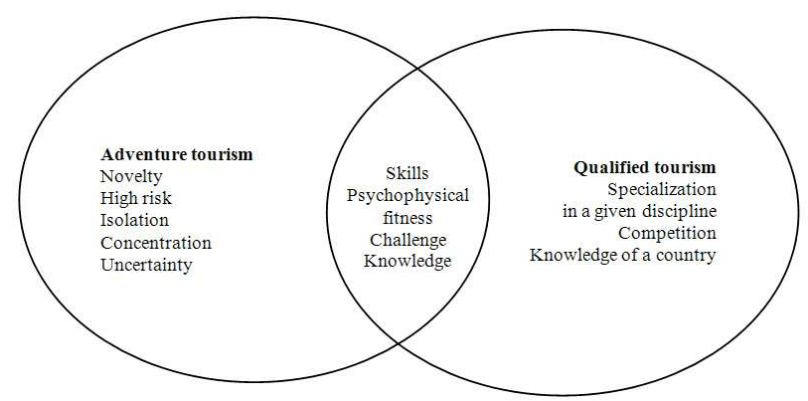

Figure 2. Selected common features of qualified and adventure tourism (narrowly defined)

The authors cited above define adventure tourism broadly as all types of tourism connected with an adventure. In particu- 
lar, however, all journeys connected with a high degree of physical activity, contact with nature, especially untouched nature, approaches to cultures that are exotic, distant and unfamiliar to tourists, journeys using mechanical vehicles (automobile, motorcycle, airplane, ship, etc.) and animals; this category also includes journeys made on foot. Adventure tourism also includes all commercial events whose main attraction is outdoor activity set in natural terrain, requiring specialized sporting (or similar) equipment and appealing thereby to tourists. Tourists not always have special abilities, e.g. in the use of this type of equipment. They may be passengers serviced by professionals, e.g. in the case of parachute jumps made in tandem [11]. Thus defined, adventure tourism offers are currently a fairly popular segment of the tourism market (Tab. 1).

Table 1. Examples of firms offering commercial expeditions within the scope of adventure tourism $[12,13,14]$

\begin{tabular}{|c|c|c|}
\hline Firm & Type of event & Characteristics \\
\hline $\begin{array}{l}\text { Country of } \\
\text { Tourism } \\
\text { (Russia) }\end{array}$ & $\begin{array}{l}\text { Trips connected } \\
\text { with space } \\
\text { tourism, } \\
\text { participation in } \\
\text { military training }\end{array}$ & $\begin{array}{l}\text { The firm offers, among other things, trips to the } \\
\text { Baikonur Cosmodrome (Kazakhstan). Viewing } \\
\text { of rocket launches, visits to the cosmodrome, } \\
\text { participation in training for cosmonauts. } \\
\text { Flights in zero gravity. } \\
\text { Flights on military MIG } 29 \text { jets. } \\
\text { Participation in military training (Russia). }\end{array}$ \\
\hline $\begin{array}{l}\text { Patagonia } \\
\text { Mountaineer- } \\
\text { ing Agency - } \\
\text { Ryszard } \\
\text { Pawłowski } \\
\text { (Poland) }\end{array}$ & $\begin{array}{l}\text { Trips connected } \\
\text { with mountaineer- } \\
\text { ing expeditions }\end{array}$ & $\begin{array}{l}\text { The firm offers mountaineering expeditions and } \\
\text { trekking in the world's highest mountains (Hima- } \\
\text { layas, Andes, Caucasus). Offer includes climbing } \\
\text { of Mt. Everest, Aconcagua, Elbrus and others. }\end{array}$ \\
\hline $\begin{array}{l}\text { HOSSEGOR } \\
\text { Surf House, } \\
\text { Camp \& } \\
\text { School } \\
\text { (France) }\end{array}$ & $\begin{array}{l}\text { Training and } \\
\text { residence } \\
\text { connected } \\
\text { with surfing }\end{array}$ & $\begin{array}{l}\text { The offer covers residence and training at a } \\
\text { surfing camp on the Bay of Biscay in France. }\end{array}$ \\
\hline $\begin{array}{l}\text { Incredible } \\
\text { Adventures } \\
\text { (USA) }\end{array}$ & $\begin{array}{l}\text { Various types of } \\
\text { adventure tourism } \\
\text { events }\end{array}$ & $\begin{array}{l}\text { The firm offers: } \\
\text { Supersonic airplane flights (USA, Russia), } \\
\text { Simulation of aerial combat (USA), } \\
\text { Tandem parachute jumps, } \\
\text { Zero gravity flight, } \\
\text { Participation in training for cosmonauts (Russia), } \\
\text { Participation in simulations of police and military } \\
\text { special operations (USA), } \\
\text { Diving with sharks, diving with whales, diving in } \\
\text { submarines, } \\
\text { Parachute jumps in the vicinity of Mt. Everest. }\end{array}$ \\
\hline
\end{tabular}

Consequently, adventure tourism is not distinguished by its scale or the form it takes; rather the most important element here is the emotional element. Whatever constitutes an adventure for a given tourist should be classified as adventure tourism. Hence, the term has a subjective character. On the other hand, an element that distinguishes between various forms of adventure tourism is, without a doubt, the increased level of risk, although even this is not essential. In literature on the subject, a distinction is made between soft adventure tourism (with a lower level of risk), adventure tourism (average risk level) and hard adventure tourism (high level of risk, often connected with extreme sports activities) [15].

As follows from the synthetic examination of the definition given above, all forms of extreme sports (so-called unusual, difficult, dangerous) activities such as climbing, diving, parasailing, flying by airplane, balloon and other aircraft, long journeys made on foot to distant and exotic places can be considered adventure tourism. Such tourism could be considered to include extreme expeditions undertaken individually or performed in small groups of enthusiasts (e.g. alpinists). Adventure tourism could also be taken to include commercial expeditions undertaken in larger groups conducted by experienced travelers. The festivals discussed in this article, without a doubt, present a theme that is particularly close to adventure tourism. They facilitate contact between enthusiasts and help promote the activities to which they are dedicated. On the other hand, they are also a factor that enlarges Lodz's tourism offer and attracts tourists - the festival's participants and spectators - to the city.

\section{Lodz festivals dedicated to adventure tourism}

\section{Explorers Festival}

The Explorers Festival was organized in Lodz in 1999, lasts five days (from Wednesday to Sunday) and takes place in the first or second week of November. This festival features film screenings, multimedia presentations, exhibitions on subjects connected with climbing, trekking, extreme skiing, parasailing, traveling, cycling, kayaking and other sports, as well as extreme expeditions. The distinguishing characteristic of the Explorers Festival is the fact that each year the festival invites personalities from the worlds of climbing, travel, extreme adventure, exploration, film and photography. These guests participate in multimedia presentations and films, where they demonstrate their wealth of experience in the area of exploration. In Poland, other festivals with similar themes are organized, e.g. the Krakow Mountaineering Festival (presentation of films on mountaineering themes), the Wondół Challenge Mountaineering Festival in Szczyrk (presentation of mountaineering expeditions). However, these have a decidedly smaller scope than the Lodz festival. The main idea guiding the festival's organizers is the promotion of an active lifestyle, extreme sports and adventure tourism through direct contact with world-famous discoverers, travelers, alpinists and persons conducting other activities of this sort. Festival spectators, many of whom are young people, are able to expand their horizons and stimulate their passion for travel thanks to contact with enthusiasts of extreme experiences. The festival also allows people with similar interests to meet each other and exchange practical experience. The idea behind the festival has been commended by the Polish Tourism Organization, which awarded the festival a Certificate for Best Tourism Product in 2008.

The precursor to the Explorers Festival was the Mountaineering Film Competition of the Lodz Mountaineering Club. This took place from 1995 to 1998, and was intended primarily for the Lodz mountain-climbing community. In 1999, the decision was made to expand the format of this event to include multimedia presentations. At this point, the name of the event was changed to the Mountain Festival. The list of organizers was expanded to include the Lodz Trekking Club, the Lodz Polytechnic and the Lodz City Hall. In 2002, the festival's format was once again expanded to include presentations concerning extreme sports and expedition presentations connected not only with mountains. At this time, the name of the festival was changed to its current designation: Explorers Festival.

At present, participation in the festival and all related activities is open and free. The event is funded by money from sponsors as well as by municipal and national subsidies. The festival is organized by volunteers, without a formal organizational structure and full-time employees. The initiators and organizers of the Explorers Festival are Zbigniew Łuczak and Jacek Sikora, renowned Polish Tatra Mountaineers. The festival's primary institutional organizer is the Lodz Trekking Club, supported by the Lodz City Hall, the University of Lodz, the Lodz Polytechnic and the National Center of Culture. Festival events take place in various locations throughout Lodz. The festival's main building is the Auditorium of the Lodz Polytechnic. Part of the events take place in the halls of the University of Lodz (Big Geography Les- 
son) and the Lodz Film, Television and Theatre School (film screenings and presentations connected with filming techniques). All in all, the Mountain Festival and the Explorers Festival have thus far (as of 2010) presented more than 170 explorers and climbers. The festival also features climbing competitions and musical events organized in well-known Lodz clubs. These have the character of accompanying events. Based on the data provided by the festival's organizers, each year between 6000 and 8000 spectators participate in the festival. Since 2006, the festival has also included the so-called Big Geography Lesson, coorganized by the Department of Geography of the University of Lodz. This lesson is an important festival event directed towards young middle-school students in Lodz and the surrounding region. Its purpose is to familiarize young people with knowledge about the world, to encourage them to spend their free time actively in contact with untouched nature and to develop passion for and sensitivity to natural values.

\section{Wreck Diving Festival}

Another festival organized in Lodz and connected with adventure tourism is the Wreck Diving Festival. By way of introduction, we begin by presenting the concept of wreck diving and its role in adventure tourism. Diving, also known as scuba-diving, involves swimming below the surface of the water (sometimes along the surface), with the use of specialized equipment (at minimum, breathing apparatus). There are many types of diving, e.g. diving while holding one's breath (without breathing apparatus), ice diving, cave diving. Diving may also take place with the use of undersea vessels, or dry, waterproof suits [7]. One type of diving is wreck diving, which arose through the combination of two disciplines, i.e. diving and archaeology. It is connected with the penetration of undersea shipwrecks, and requires specialized skills and historical and archaeological interests. Wreck diving is connected with penetration of already discovered, fixed objects, but also with the discovery of unknown wrecks in areas where human maritime activity has taken place, e.g. former trade routes, travel routes or the sites of sea battles [16]. Wreck diving enthusiasts organize themselves into clubs and organize expeditions whose purpose is to penetrate wrecks and discover their locations. Accordingly, these are people who practice adventure tourism, because this form of expedition fulfills all of the previously mentioned features of this type of tourism.

Thus far, a single edition of the Wreck Diving Festival has been organized, in March of 2010. The festival took the form of a presentation of films connected with wreck diving. Its purpose was to present features of wreck diving, to demonstrate differences between wreck diving and other types of diving. During the festival, expeditions were presented whose purpose was to penetrate wrecks (mainly in the Baltic Sea). Presentations were also given of wreck diving techniques and expedition plans. During the festival, spectators were also given a chance to listen to shanty songs, talk with divers and exchange experiences.

The festival was organized by the TRYTON Lodz Diving Club, together with the Wreck Expedition Association. Patrons that supported the festival with regard to organization, finance and media included trade magazines connected with diving, the Batysfera Diving Center, Keja Pub, TVP3. The first Wreck Diving Festival was a one-day event that took place in Lodz's Keja Pub, a place popular with lovers of the sea and water sports. Around 160 people participated in the festival. Participation required a ticket. A second edition of the Wreck Diving Festival is planned for 2011. It will have a character similar to that of the 2010 festival.
It should be emphasized that the festival described above has already become a fairly well-known event within the diving community. The organizers are also intensively promoting a new edition of the festival for 2011. The promotion is taking place through websites, branch-specific press, the sending of invitations to diving associations. To aid in realizing another edition of the festival, the organization has established cooperation with new institutions, including the government of the city of Lodz. The Wreck Diving Festival is, in comparison with the Explorers Festival, a smaller, more specialized event that is just starting out. It does not really have a chance to attain the level of popularity achieved by the Explorers Festival. However, in the future it certainly has a chance to develop and achieve a good position admittedly a niche - among diving enthusiasts on the Lodz market for festivals connected with adventure tourism.

\section{Analysis of opportunities and threats (SWOT)}

The Explorers Festival and Wreck Diving Festival described in this article constitute tourism products of importance to Lodz municipal tourism. For this reason, the authors have decided to analyze the opportunities and threats, designated in trade literature with the acronym SWOT (strengths, weaknesses, opportunities, threats). The weaknesses and strengths consist of internal factors, i.e. those connected with the structure of the organization or undertaking being assessed. The opportunities and threats, on the other hand, apply to external situations, i.e. the environment [4]. This analysis is one of the most frequently encountered tools used in assessing the status of an enterprise, institution, undertaking or the tourism potential of a given area. The SWOT analysis conducted in this article has been adapted to the assessment of the developmental perspectives of the aforementioned festivals within the context of their role in promoting adventure tourism and their impact on the formation and development of tourism in Lodz (Tab. 2).

In the analysis, positive features decisively predominate for both festivals, i.e. strengths and opportunities. The Explorers Festival has a decidedly stronger trademark and a longer tradition, and can be treated as a star tourism product. It attracts numerous participants, and does not require intensive promotion to maintain its position on the tourism market. The Wreck Diving Festival, on the other hand, has a different character. By its very nature it is a more specialized event that is only just beginning to function on the Lodz festival market. However, it has a chance to develop itself into a serious festival offering, providing it continues to function, develop and be promoted.

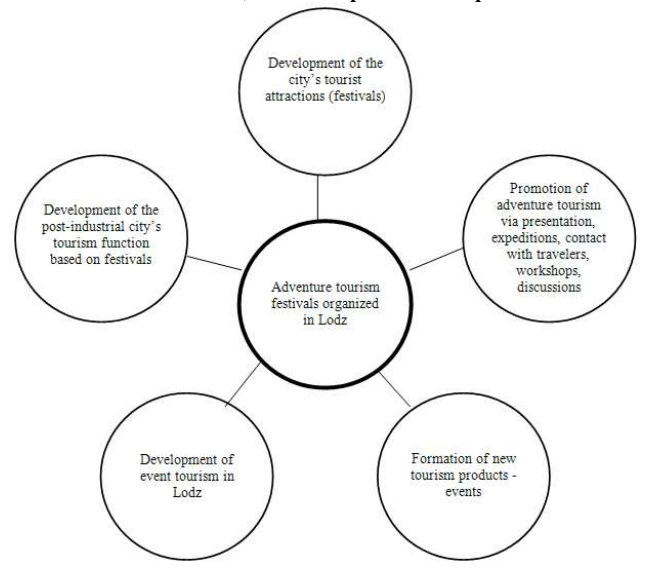

Figure 3. Role of festivals connected with adventure tourism in developing tourism in Lodz 
Table 2. SWOT analysis for Explorers Festival and Wreck Diving Festival

\begin{tabular}{|c|c|c|}
\hline Festival & Positive Factors & Negative Factors \\
\hline \multirow[b]{2}{*}{ 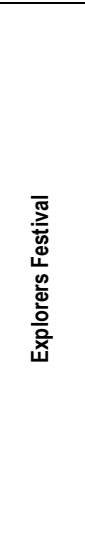 } & $\begin{array}{ll}\text { Strengths } \\
\end{array}$ & Weaknesses \\
\hline & $\begin{array}{l}\text { Engagement of the travel and climbing communities in } \\
\text { organizing the festival. } \\
\text { Attended by unique personalities from Poland and } \\
\text { abroad. } \\
\text { Long festival tradition, well-known. } \\
\text { Interesting and fashionable festival subject. } \\
\text { Engagement of numerous public institutions. } \\
\text { Acquisition of numerous private sponsors. } \\
\text { Free entry. } \\
\text { Good promotion. } \\
\text { Very good location base for festival needs. } \\
\text { Thematic and categorical diversity of events: presenta- } \\
\text { tions on travel, tourism, sports, extreme sports, journal- } \\
\text { ism, film. } \\
\text { Various forms of presentation: meetings with travelers, } \\
\text { workshops, e.g. photography, multimedia and film } \\
\text { presentations. } \\
\text { Contact with professionals, opportunity to share expe- } \\
\text { riences. }\end{array}$ & $\begin{array}{l}\text { Dependence on spon- } \\
\text { sors and public institu- } \\
\text { tions that support the } \\
\text { institution due to free } \\
\text { entry and lack of a } \\
\text { dedicated festival } \\
\text { building. } \\
\text { Dependence on volun- } \\
\text { teers, because the entire } \\
\text { festival is prepared on a } \\
\text { voluntary basis. } \\
\text { High quality, but too } \\
\text { small as regards the } \\
\text { number of audience } \\
\text { members in the festival's } \\
\text { main projection hall } \\
\text { (Auditorium of the Lodz } \\
\text { Polytechnic). }\end{array}$ \\
\hline 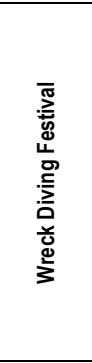 & $\begin{array}{l}\text { Engagement of the Lodz diving community in organizing } \\
\text { the festival. } \\
\text { Festival guests who are known within the community. } \\
\text { Interesting theme belonging to a new trend in adventure } \\
\text { tourism. } \\
\text { Possibility of viewing presentations of diving expeditions } \\
\text { and planned future expeditions. } \\
\text { Contact with professionals, opportunity to share expe- } \\
\text { riences. }\end{array}$ & $\begin{array}{l}\text { Local base too weak for } \\
\text { festival needs. } \\
\text { Festival in development } \\
\text { stage, need to consoli- } \\
\text { date image and develop } \\
\text { the product. } \\
\text { Event dedicated to a } \\
\text { narrow theme - wreck } \\
\text { diving - limited group of } \\
\text { addressees. } \\
\text { Expensive entry tickets, } \\
\text { problems acquiring } \\
\text { external financing. }\end{array}$ \\
\hline & Opportunities & Threats \\
\hline 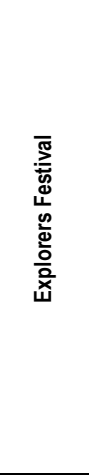 & $\begin{array}{l}\text { Development of new trends in tourism, including devel- } \\
\text { opment of adventure tourism. } \\
\text { Increase in festival expenditures in Lodz due to the } \\
\text { increasing role played by tourism in the city. } \\
\text { High level of interest in the festival among young people, } \\
\text { primarily students. Increasing attractiveness of Lodz for } \\
\text { tourists, as a result of: development of festivals and other } \\
\text { tourists attractions in the city, growth of the tourist service } \\
\text { sector (e.g. hotels), development of transport infrastruc- } \\
\text { ture (roads, airport). }\end{array}$ & $\begin{array}{l}\text { High level of competition } \\
\text { from other Lodz festivals } \\
\text { taking place at the same } \\
\text { time, e.g. the Festival of } \\
\text { Christian Culture, the } \\
\text { Tansman Festival, the } \\
\text { Humanity in Danger } \\
\text { Media Festival, etc. } \\
\text { Global economic crisis } \\
\text { limiting interest in } \\
\text { tourism and festivals. } \\
\text { Competition from other } \\
\text { similar festivals in Poland } \\
\text { and around the world. } \\
\text { Lodz's negative image } \\
\text { among the residents of } \\
\text { other cities in Poland. }\end{array}$ \\
\hline 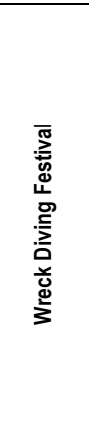 & $\begin{array}{l}\text { Development of diving in Poland after } 1989 . \\
\text { Increased interest in wreck diving, e.g. in the Baltic Sea. } \\
\text { Nearness of a sea (Baltic), containing numerous ship- } \\
\text { wrecks. } \\
\text { Possibility of organizing expeditions. } \\
\text { Increase in the number of scuba-diving clubs in Poland. } \\
\text { Establishment of organizational cooperation with city } \\
\text { authorities. } \\
\text { Increasing attractiveness of Lodz for tourists, as a result } \\
\text { of: development of festivals and other tourists attractions } \\
\text { in the city, growth of the tourist service sector (e.g. } \\
\text { hotels), development of transport infrastructure (roads, } \\
\text { airport). } \\
\text { Very little competition from other festivals, few of which } \\
\text { take place in February/March (when the festival is } \\
\text { organized). }\end{array}$ & $\begin{array}{l}\text { Global economic crisis } \\
\text { limiting interest in } \\
\text { tourism and festivals. } \\
\text { High cost of diving and } \\
\text { diving expeditions. Niche } \\
\text { character of wreck } \\
\text { diving. } \\
\text { Lodz's negative image } \\
\text { among the residents of } \\
\text { other cities in Poland. }\end{array}$ \\
\hline
\end{tabular}

\section{Conclusions}

The festivals described in this article constitute an element of functional changes in Lodz, influencing, among other things, the development of Lodz's tourism offer (Fig. 3). They also promote adventure tourism among festival attendees. Their role in promoting adventure tourism is in this case extremely important, because they inspire dreams and facilitate contact with famous explorers from all over the globe. This is even more important given that the majority of attendees are young people, including students. In addition, the Explorers Festival includes the Big Geography Lesson, which is directed towards middle-school students from Lodz and the surrounding area. As a result, ideas connected with adventure tourism are promoted among young people. Their interests are developed, their curiosity about the world is stimulated, and their approach to nature is refined.

\section{Literature}

1. Cudny, W. (2006). The Four Cultures Dialog Festival as an example of a strategic tourism product for the city of Lodz. Turystyka i Hotelarstwo 10, 117-128. [in Polish]

2. Cudny, W. (2011). Film Festivals in Łódź as a main component of urban cultural tourism. Bulletin of Geography, Socioeconomic Series. 15, 131-141. DOI: 10.2478/v10089-0110009-6.

3. Kowalczyk, A. (2001). The Geography of Tourism (1 ${ }^{\text {st }}$ edition). Warsaw: PWN. [in Polish]

4. Kaczmarek, J., Stasiak A. \& Włodarczyk B. (2010). The tourism product. Idea, organization, management ( $2^{\text {nd }}$ edition). Warsaw: PWE. [in Polish]

5. Von Rohrscheidt, A.M. (2008). Cultural Tourism. Phenomenon, Potential, Perspectives ( $1^{\text {st }}$ edition). Gniezno: GWSHM Milenium w Gnieźnie. [in Polish]

6. Łobożewicz, T. (1983). Qualified Tourism (1 ${ }^{\text {st }}$ edition). Warsaw: Wyd. PTTK Kraj. [in Polish]

7. Merski, J. \& Warecka J. (2009). Qualified tourism. Active tourism ( $1^{\text {st }}$ edition). Warsaw: AlmaMer Wyższa Szkoła Ekonomiczna. [in Polish]

8. Hudson, S. (Red.) (2003). Sport and adventure tourism (1 $1^{\text {st }}$ edition). New York, USA: The Haworth Hospitality Press.

9. Durydiwka, M., Jarzębowska M., Kowalczyk A., Kulczyk S., Kurkowska A. \& Lewandowski W. (2010). Qualified tourism (active tourism) as a form of sustainable tourism. In A. Kowalczyk (Ed.), Sustainable tourism (pp. 249-289). Warsaw: PWN. [in Polish]

10. Swarbrooke, J., Beard C., Leckie S. \& Pomfret G. (2003). Adventure tourism. The new frontier ( $1^{\text {st }}$ edition). Burlington: Butterworth-Heinemann.

11. Buckley, R. (2006). Adventure Tourism (1 ${ }^{\text {st }}$ edition). Oxfordshire: CABI.

12. http://www.patagonia.com.pl/ - access date Jan. 2011. [in Polish]

13. http://www.nomadsurfers.com/ - access date Jan. 2011.

14. http://www.incredible-adventures.com/ - access date Jan. 2011.

15. Durydiwka, M. (2003). Adventure tourism. Prace i Studia Geograficzne 32, 159-172. [in Polish]

16. Mountain, A. (2010). Everything about Diving ( $1^{\text {st }}$ edition). Warsaw: Bellona S.A. [in Polish]

Submitted: January 25, 2011

Accepted: June 16, 2011 